УдК 338.5; 004.9

\title{
НЕДОЛІКИ ТА ШЛЯХИ МОДЕРНІЗАЦІЇ СИСТЕМИ ЦІНОУТВОРЕННЯ В БУДІВНИЦТВІ ІЗ ЗАСТОСУВАННЯМ ВЕЛИКИХ МАСИВІВ ДАНИХ (ВIG DATА)
}

\author{
DISADVANTAGES AND WAYS TO MODERNIZE \\ THE SYSTEM OF PRICING IN CONSTRUCTION \\ WITH THE USE OF LARGE DATA SETS (BIG DATA)
}

\author{
Герасимова Оксана Леонідівна \\ кандидат технічних наук, доцент, \\ Придніпровська державна академія будівництва та архітектури \\ ORCID: https://orcid.org/0000-0003-0163-7831 \\ Herasymova Oksana \\ Prydniprovska State Academy of Civil Engineering
}

\begin{abstract}
Актуальність теми статті визначається тим, що стабільний розвиток України неможливо уявити без значних темпів росту прямих іноземних інвестицій, які залежать від наявності сприятливого ділового клімату в країні. Багатогранний процес включає комплексну державну політику в сфері впровадження прозорих та сучасних методів ціноутворення в будівництві. Гнучка та інформативна система визначення вартості будівництва повинна базуватися на використанні програмних інструментів управління великими даними. Закордонні методи визначення кошторисних цін достатньо давно базуються на системному процесі збору та обробки інсрормації з відкритих джерел. Збірники кошторисних цін у розвинутих країнах не є примусовими загальнообов'язковими вимогами, норми не затверджуються центральними органами виконавчої влади або місцевого самоврядування та не вводяться в дію будь-якими інстанціями. Вітчизняні методи ціноутворення срактично продовжують копіювати радянську систему розробки кошторисної документації, що не дає можливості інвесторам робити зважений вибір між багатоваріантними проектними рішеннями, а також своєчасно контролювати ефрективність управлінських рішень за допомогою інтерактивних технологій.
\end{abstract}

Ключові слова: ціноутворення в будівництві, кошторисна справа, великі дані, прямі інвестиції, обробка інсормації.

Актуальность темы статьи определяется тем, что стабильное развитие Украины невозможно представить без значительных темпов роста прямых иностранных инвестиций, которые зависят от благоприятного делового климата в стране. Многогранный процесс включает в себя комплексную государственную политику в сорере внедрения прозрачных и современных методов ценообразования в строительстве. Гибкая и информативная система определения стоимости строительства должна основываться на использовании программных инструментов управления большими данными. Зарубежные методы определения сметных цен достаточно давно базируются на системном процессе сбора и обработки инсрормации из открытых источников. Сборники сметных цен в развитых странах не являются принудительными общеобязательными требованиями, нормы не утверждаются центральными органами исполнительной власти или местного самоуправления и не вводятся в действие какими-либо инстанциями. Отечественные методы ценообразования фрактически продолжают копировать советскую систему разработки сметной документации, что не позволяет инвесторам производить взвешенный выбор между многовариантными проектными решениями, а также своевременно контролировать эффективность управленческих решений с помощью интерактивных технологий.

Ключевые слова: ценообразование в строительстве, сметное дело, большие данные, прямые инвестиции, обработка инсрормации.

Relevance of the article is determined by the fact that stable development of Ukraine cannot be imagined without significant growth rates of direct foreign investments, which depend on the presence of a favorable business climate in the country. A comprehensive state policy in the field of implementation of innovative and modern methods of price formation in the construction industry is a rich process. A sound and informative system of construction cost estimation should be based on the use of modern software tools of big data management. Foreign methods of determining quotation prices for a long time based on a systematic process of collection and processing of information from open 
sources. The cost price lists in developed countries are not prima facie binding requirements; the standards are not approved by the central bodies of executive power or local self-government and are not enacted by any authorities. The domestic methods of price formation actually continue to copy the radical system of development of quotation documentation, the price does not allow investors to make a reasonable choice between lucrative project solutions, as well as to adequately control the efficiency of management decisions using interactive technologies. The era of information technology is a new feature in the cost management business, which will not only allow automatic collection, filtering and processing of large amounts of data, but also use analytical platforms for modeling and rapid optimization of individual indicators of the cost of projects. Traditional management methods are gradually receding into the background, new realities urge national economies to switch to wide use of informational systems of decision-making support (GDSS), which are based on the tools of piecemeal intellect (machine learning). Ukrainian estimators repeatedly paid attention to accumulated foreign experience in the system of price formation. Ukraine does not use its competitive advantages in the field of information technology for modernization of approaches to compilation of pricing standards. The best data processing tools allow you to analyze the information obtained, to develop a visualization of advanced design solutions, taking into account the stimulating indicators of cost allocations.

Keywords: pricing in construction, estimating, big data, direct investments, information processing.

Постановка проблеми. Існуюча централізована система використання кошторисних нормативів у будівництві зосталася в спадок Україні від планової економіки СРСР, залишаючись суто пострадянським рудиментом, вона продовжує відштовхувати від вітчизняної економіки іноземних інвесторів. Доволі заплутані та складні підходи, методи та норми, які на протязі багатьох десятирічь продовжують застосовувати при визначенні ціни на будівельну продукцію, можуть бути вигідними для певних груп: по-перше, в їхньому тривалому існуванні зацікавлені безпосередньо розробники; по-друге, вони потрібні контролюючим та фріскальним органам, адже передбачають регулярний перегляд нормативно-методичного забезпечення, а також потребують постійної консультаційної підтримки та систематичних додаткових фрінансових витрат користувачів, до того ж, передбачають безліч можливих штрафних санкцій, адміністративну та кримінальну відповідальність за порушення законодавчих нормативних актів.

Аналіз останніх досліджень і публікацій. Проблеми ресрормування вітчизняної системи ціноутворення в будівництві були висвітлені в роботах А. Беркути, Н. Куденко, В. Резниченко, Н. Ленінцева, Ю. Суровцевої, Л. Кузняк та ін. Автори вказували на неможливість використання в якості бази ціноутворення нормативних систем, які були розроблені ще в радянські часи. Наприклад, Ю. Суровцева писала, що сучасна система ціноутворення зберегла більшість недоліків радянської системи [1, с. 277]. Проблема підвищення транспарентності діяльності будівельного підприємства активно підіймалася у роботах В. Халіної та О. Сироватського, які акцентували увагу на те, що великі обсяги інформації потребують нових методів управління будівельним підприємством [2; 3]. Також відмітимо актуальність спроби класи- фрікувати витрати сучасного будівельного підприємства для оперативного управлінського обліку в працях О. Павелко [4].

Виділення невирішених раніше частин загальної проблеми. В умовах глобалізації, децентралізації та перманентного реформування української економіки, система ціноутворення в будівництві, що базується на державних нормах та стандартах, повинна поступово трансорормуватися у відкриту інфрормаційну систему, яка б відповідала сучасним потребам інвесторів та полегшувала б працю користувачів-кошторисників. Чим легшою, зрозумілою та більш сумісною з іншими програмними комплексами буде система ціноутворення в будівництві, тим меншою буде очікувана корупційна складова в інвесторській документації.

Формулювання цілей статті (постановка завдання). Метою статті $€$ вивчення перспективного закордонного досвіду ціноутворення в будівництві задля покращення вітчизняних методів визначення кошторисної вартості будівельних проектів.

Виклад основного матеріалу дослідження. В промислово розвинених країнах система ціноутворення в будівництві базується на ІНФОРМАЦії, на зборі й аналізі первинних даних спеціалізованих будівельних компаній (рис. 1), через це кошторисна справа є більш прозорою, гнучкою та інформативною. Великі масиви даних (Big Data) активно використовуються в будівельній ссрері промислово розвинутих країн на протязі багатьох десятирічь, саме тому, по темпах збору інорормації та ведення аналітики, Україна відстає від США, $€ С$ та «азійських тигрів» на десятки років.

Прикладами для наслідування можуть бути північноамериканська (США, Канада) та європейська системи ціноутворення. Наприклад, цікавими $€$ спроби Білорусі розглянути можливість використання німецького 
досвіду, німецьких стандартів DIN 276 Kosten im Hochbau, DIN 277 Grundflächen und Rauminhaltevon Bauwerken im Hochbau, які за багатьма позиціями повторюють американські, канадські та фрранцузькі методи ціноутворення в будівництві.

Стосовно українських реалій, достатньо навести цитату зі статті «Улучшение проектно-сметного дела», надрукованої в журналі «Экономика строительства» від 1982 року, один 3 авторів якої був замісник Держбуду СРСР: «основа этой системы - элементные сметные нормы на строительные работы, содержащие оптимальные данные о материальных и технических ресурсах, необходимых для выполнения каждого вида работ» [5, с. 57]. Тобто, за останні сорок років ціноутворення в будівництві системно не змінювалося. Реформування проектнокошторисної справи звелося до відмови від вартісних показників у негнучких державних нормативах [6]. Окрім того, спостерігаємо певне погіршення ситуації, тому що планова економіка активно використовувала на практиці не тільки одиничні розцінки, а й укрупнені кошторисні норми (укрупненные сметные нормы (УСН)), укрупнені показники вартості будівництва (укрупненные показатели стоимости строительства (УПСС), укрупнені розцінки (укрупненные расценки (УР)) - зручні нормативні бази для швидкого розрахунку кошторисної вартості, які зараз не розробля- ються та не використовуються Міністерством розвитку громад та територій України, незважаючи на нагальну потребу в їх існуванні.

Залученню іноземних інвестицій в Україну заважають не стільки довгий шлейфр корупційних скандалів, шокуючі фракти силового рейдерства, нерівномірність розподіленого між платниками податків фріскального тягаря чи складність інструментів адміністрування податків, скільки незрозумілий, фактично пострадянський, механізм ціноутворення в будівництві, який гостро потребує сучасної транссоормації у гнучку та інсоормативну систему, цілком зрозумілу для потенційних інвесторів. Технології автоматизації процесів збору та обробки кошторисних даних сприятимуть виведенню будівельної галузі 3 тіні, зменшенню впливу срінансовопромислових груп на економіку, припиненню порушень контрактів. Першим майданчиком для перезавантаження системи ціноутворення в будівництві може стати система державних закупівель та тендерних пропозицій Prozzoro, яка може збирати та акумулювати отриману інсоормацію відносно вартісних показників проведених будівельних тендерів. Також інфрормативними будуть ринкові дані, що розміщені на сайтах будівельних компаній або на сайтах подібних https://www.rabotniki.ua/.

Відзначимо, що до акту агресії 2014 року, Україна копіювала російську модель ринкової економіки в будівництві, повторювала систему соціально-економічних відносин між

Визначення вартості будівництва

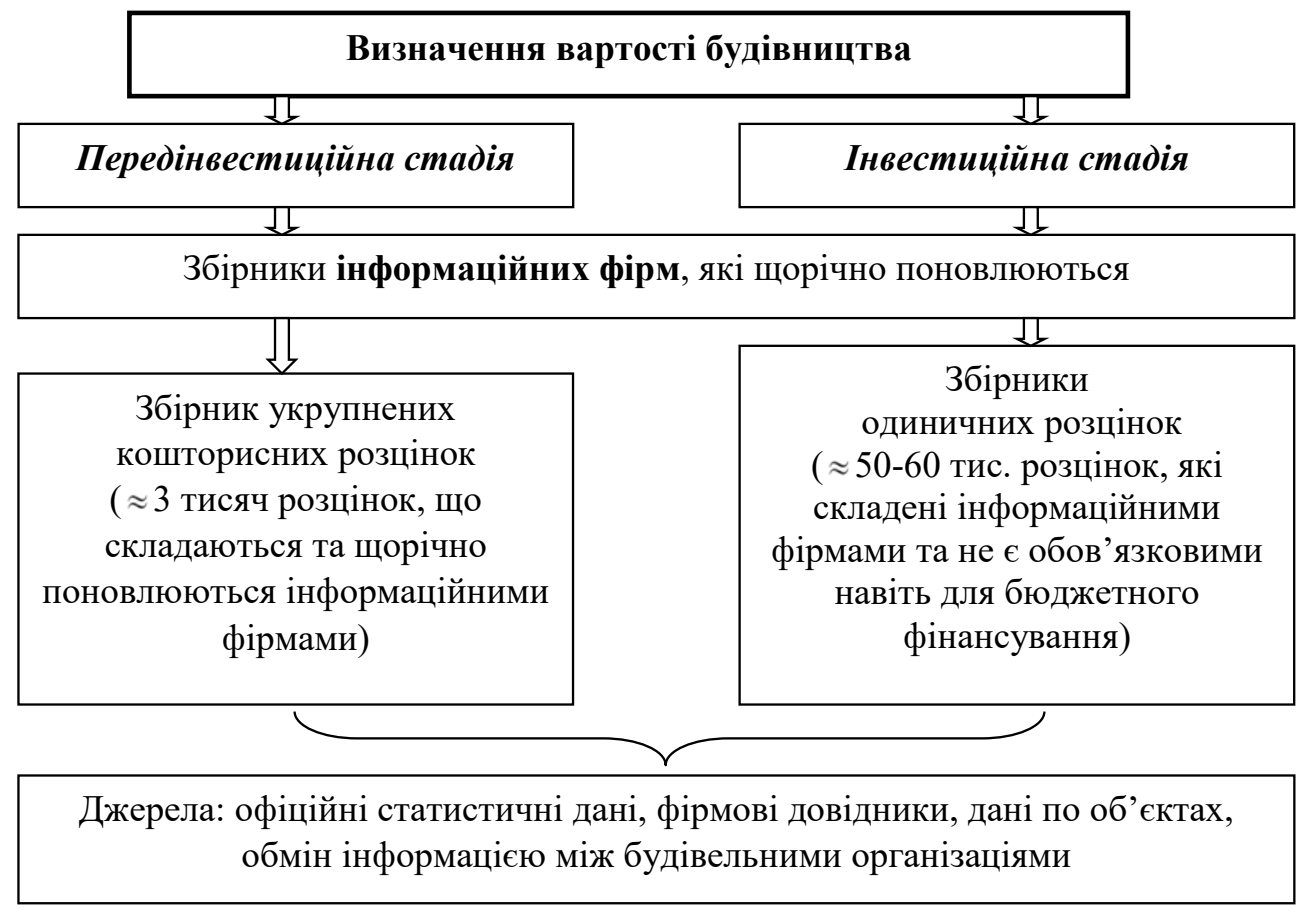

Рис. 1. Особливості визначення вартості будівництва у США 
працівниками, роботодавцями та державою, а також наслідувала корупційні схеми Мінрегіону Росії та інших державних установ. Те, що в сусідньої держави не все гаразд, можна побачити на прикладі перевірок слідчого комітету: в 2015 році ним була проведена перевірка діяльності ФАУ «ФЦЦС» (Федеральное автономное учреждение «Федеральный центр ценообразования в строительстве и промышленности строительных материалов»), яка встановила, що більшість індивідуальних та галузевих нормативів були розроблені асрілійованими комерційними структурами, пов'язаними із посадовими особами ФАУ «ФЦЦС» та членами їх сімей; у відповідності з дорученнями фрінансово зацікавлених осіб, структури займалися розробкою та розповсюдженням програмного забезпечення, навчанням, атестацією кадрів, видавничою діяльністю. Отже, українська система ціноутворення в будівництві потребує модернізації із застосуванням позитивних сррагментів міжнародного досвіду.

Сучасна епоха інформаційних технологій передбачає, що практично кожне оптимальне управлінське рішення базується на зборі та аналізі даних (Data Mining). Це дозволяє уникати стратегічних помилок та підвищувати фрінансову стабільність діяльності компанії. Відфрільтровані та оброблені дані дають оптимальні відповіді та рекомендації по кожному варіанту конструктивних рішень проекту, через це ціноутворення в будівництві можна розглядати як складну адаптивну систему (САC), яка постійно обмінюється з оточенням корисною інформацією, при цьому використовує накопичений практичний досвід та своєчасно адаптується до можливих змін у зовнішньому середовищі (рис. 2).

Новітні циоррові технології примушують бізнес плавно переходити від жорсткого нормування використання ресурсів до гнучких цифрових технологій, які базуються на відкритій інфрормації.

Наприклад, британська компанія Arabesque розробила стартап, який дозволяє визначати стійкість компаній на базі алгоритмів нейронних мереж та «великих даних», які можливо знайти у відкритих джерелах (приблизно 50000 джерел). Самі відкриті джерела дозволяють давати об'єктивну, не застарілу інформацію щодо діяльності бізнесу для аналітиків, що дає змогу розробникам програм 3 кожним роком вдосконалювати систему обробки даних, за умов, що показники діяльності бізнесу будуть більш доступними, прозорими та відкритими, що дозволить інвесторам приймати ефективні рішення на базі новітніх цифррових технологій, які стають рушійною силою світової економіки [7].

Подібна система може використовуватися інвесторами для оцінки ризиків будівельних проектів, а також для оцінки кошторисної вартості та ефрективності проекту. Відносно українських реалій, можемо відмітити: будівельні компанії неохоче діляться інорормацією щодо своєї діяльність у відкритих джерелах, вважаючи більшість даних комерційною таємницею або коноріденційною інфрормацією, поширення якої можливе лише за згодою компанії. Не $є$ комерційною таємницею інфрормація, яка надається Державній службі статистики, Державній фріскальній службі України, а саме [8]:

- Форма №1 «Баланс» (Звіт про фрінансовий стан);

- Форма № 2 «Звіт про фрінансові результати» (Звіт про сукупний дохід);

- Форма № 5 «Примітки до річної фрінансової звітності»;

- Звіт про прийнятий в експлуатацію закінчений будівництвом об'єкт (Наказ від 05.08.2014 № 225 (зі змінами)), 2-буд, квартальна;

- Звіт про виконання будівельних робіт (Наказ від 05.08.2014 № 225 (зі мінами)), 1-кб, місячна;

- Інфрормація про об'єкт, на який отримано документ на виконання будівельних робіт (Наказ від 16.11.2015 р. № 331 (зі змінами)). 1-буд, квартальна;

- Структурне обстеження підприємства (Наказ від 29.09.2014 № 273 (зі змінами)), 1-підприємництво, річна.

Іншу інорормацію можливо знайти завдяки непрямому аналізу даних, які потрапляють у відкритий інсрормаційний простір: інтернет,



Рис. 2 
реклама, газети, журнали, конференції. Через те що вітчизняне будівництво пов'язане не тільки корупційними, а й кримінальними схемами, 3 відмиванням брудних грошей та вкладанням незаконно отриманих статків у об'єкти, наразі важко уявити можливість роботи з відкритими даними. Модернізацію системи ціноутворення в будівництві треба пов'язувати 3 комплексним рефрормуванням системи державного управління, судочинства та пов'язаних антикорупційних механізмів.
Висновки. Будівельний комплекс пострадянських країн потребує наявності послідовних процесів, які будуть направлені на: всебічну транссрормацію системи розробки та затвердження кошторисної документації; державну підтримку використання регіональних індексів цін у будівельній галузі; оперативну розробку механізму використання укрупнених нормативів, який допоможе визначати кошторисну вартість як окремих конструктивних елементів будівлі, так і ціну будівництва взагалі.

\section{СПИСОК ВИКОРИСТАНИХ ДЖЕРЕЛ:}

1. Суровецева Ю.В. Синергетичні підходи до систем ціноутворення будівельної продукції в умовах ринку. Коммунальное хозяйство. ХНУМГ ім. Бекетова. 2008. № 85. С. 277-281.

2. Халіна В.Ю., Сироватський О.А. Транспарентність діяльність будівельного підприємства як детермінант довіри стейкхолдерів. Економічний простір. 2020. № 155. С. 74-80.

3. Халіна В.Ю., Сироватський О.А., Покуса Т. Транспарентність будівельного підприємства. Європейський вектор модернізації економіки: креативність, прозорість та сталий розвиток : матеріали XII Міжнародної науково-практичній консреренції. 27-28 травня 2020 року, м. Харків : ХНУБА, 2020. С. 285.

4. Павелко О.В. Витрати у будівництві: ідентифрікація економічної сутності, нормативно-правове регулювання обліку та відображення у звітності. Вісник ЖДТУ. 2016. № 4. С. 93-101.

5. Алексеев В.А., Апарин И.Л., Козьмич Ю.А. Улучшение проектно-сметного дела. Экономика строительства. 1982. № 2. С. 52-61.

6. Беркута А.В. Система ресрормування ціноутворення у будівництві України : дис. ... канд. екон. наук : 08.07.03 / Київський національний ун-т будівництва і архітектури. Київ, 2002. 203 с.

7. Орешкина А., Маккейл К. Британский стартап заглянет бизнесу «под кожу» интернет-издание «ИнвестФорсайт». URL: https://www.if24.ru/zaglyanut-biznesu-pod-kozhu/

8. Правила визначення вартості будівництва. ДСтУ Б д.1.1-1:2013. - Мінрегіон України, 2013: Мінрегіон України, НВФ «Інпроект». URL: http://www.minregion.gov.ua/wp-content/uploads/2015/12/DSTU1.1-1_z_-Zm_ noyu-1.pdf

\section{REFERENCES:}

1. Surovetseva Yu V. (2008) Synerhetychni pidkhody do system tsinoutvorennia budivelnoi produktsii v umovakh rynku [Synergetic approaches to pricing systems for construction products in market conditions]. Kommunalnoe khoziaistvo. KhNUMH im. Beketova, no. 85, pp. 277-281.

2. Khalina V.Iu., Syrovatskyi O.A. (2020) Transparentnist diialnoisti budivelnoho pidpryiemstva yak determinant doviry steikkholderiv [Transparency of the construction company as a determinant of stakeholder confidence]. Ekonomichnyi prostir: Zbirnyk naukovykh prats, no. 155, pp. 74-80.

3. Khalina V.Iu., Syrovatskyi O.A., Pokusa T. (2020) Transparentnist budivelnoho pidpryiemstva [Transparency of the construction company]. Yevropeiskyi vektor modernizatsii ekonomiky: kreatyvnist, prozorist ta stalyi rozvytok: materialy XII Mizhnarodnii naukovo-praktychnii konferentsii, p. 285.

4. Pavelko O.V. (2016) Vytraty u budivnytstvi: identyfikatsiia ekonomichnoi sutnosti, normatyvno-pravove rehuliuvannia obliku ta vidobrazhennia u zvitnosti [Charges in building: authentication of economic essence, normatively and legal adjusting of account and reflection in accounting]. Visnyk ZhDTU, no. 4, pp. 93-101.

5. Alekseev V.A., Aparyn Y.L., Kozmych Yu.A. (1982) Uluchshenye proektno-smetnoho dela [Improvement of project and estimate business]. Ekonomyka stroytelstva, no. 2, pp. 52-61.

6. Berkuta A.V. (2002) Systema reformuvannia tsinoutvorennia u budivnytstvi Ukrainy [The system of pricing reform in the construction of Ukraine]. (PhD Dissertation), Kyiv: Kyiv National University Building and Architecture.

7. Oreshkyna A., Makkeil K. (2018) Brytanskyi startap zahlianet byznesu «pod kozhu» [British start-up will glance to business «under a skin»]. «Ynvest-Forsait». Available at: https://www.if24.ru/zaglyanut-biznesu-pod-kozhu/

8. Minrehion Ukrainy, NVF «Inproekt». Pravyla vyznachennia vartosti budivnytstva. DSTU B D.1.1-1:2013 (2013) [Rules of determination of building cost]. DSTU B D.1.1-1:2013]. Available at: http://www.minregion.gov.ua/ wp-content/uploads/2015/12/DSTU1.1-1_z_-Zm_noyu-1.pdf 